Wider application of ion exchange in extractive hydrometallurgy therefore seems likely.

Table X. Cost of Ion Exchange: Assumed Plant, 1 Tpd $\mathrm{U}_{3} \mathrm{O}_{8}$

\begin{tabular}{|c|c|c|}
\hline & Dollars per Day & $\begin{array}{c}\text { Cents per } \mathrm{Lb} \\
\mathrm{U}_{3} \mathrm{O}_{8}\end{array}$ \\
\hline $\begin{array}{l}\text { Resin at } 20 \text { pct per year on } \$ 54,000 \\
\text { Equipment at } 10 \text { pet per year }\end{array}$ & 33 & 1.65 \\
\hline $\begin{array}{l}\text { on } \$ 320,000 \\
\text { Labor, supervision, and overhead } \\
\text { Maintenance at } 4 \text { pct per year }\end{array}$ & $\begin{array}{l}100 \\
128\end{array}$ & $\begin{array}{l}5.0 \\
6.4\end{array}$ \\
\hline $\begin{array}{l}\text { on equipment } \\
\text { Elution acid, } \mathrm{HCl} \text { or } \mathrm{HNO}_{3} \\
\text { Elution alkali, } \mathrm{MgO} \text { or } \mathrm{NH}_{3} \\
\text { Miscellaneous chemicais } \\
\text { Water } \\
\text { Power }\end{array}$ & $\begin{array}{r}40 \\
92 \\
65 \\
10 \\
7 \\
12\end{array}$ & $\begin{array}{l}2.0 \\
4.6 \\
3.25 \\
0.5 \\
0.35 \\
0.6\end{array}$ \\
\hline Total & $\$ 487$ per day & $24.35 \notin$ per $\mathrm{lb}$ \\
\hline
\end{tabular}

Acknowledgments

The authors wish to acknowledge assistance from the various staff members of the Massachusetts Institute of Technology Mineral Engineering Laboratory, Watertown, Mass., including R. Schuhmann, Jr., N. Schiff, F. N. Oberg, J. J. Brunner, D'Arcy George, David Kaufman, George Lower, R. Kennedy, Sara Bailey, R. Barnard, and C. Abrams. This paper is based largely on work done under contract from the Raw Materials Div., AEC, under Jesse C. Johnson and George Marvin, by Massachusetts Institute of Technology. Operation of the Laboratory under AEC contract has been continued from 1951 to 1954 by American Cyanamid Co., and 1954 to date by National Lead Co. Special thanks go to D'Arcy George and R. Kennedy, who helped gather the data for this paper.

\section{References}

I S. Sussman and A. B. Mindler: Chemical Industries, May 1945. 2 A. B. Mindler and C. F. Paulson: Journal of Metals, 1953, vol, 5 , No. 3, p. 980 .

${ }^{3}$ R. Kunin: Industrial and Engineering Chemistry, 1948, vol. 40, p. $41 ; 1949$, vol. 41 , p. $55 ; 1950$, vol. 42 , p. $65 ; 1951$, vol. 43 , p. 102; 952 , vol. 44 , p. 79 ; 1953 , vol. 45 , p. 83 ; 1954 , vol. 46 , p. 118 .

4 G. A. Lutz: Battelle Technical Review, June 1953.

5 South African Mining and Engineering Journal, 1952, p. 243.

Chemical Engineering, 1953, vol. 60, No. 2, p. 198

7 A. M. Gaudin: Principles and New Developments in Uranium Leaching, International Conference on the Peaceful Uses of Atomic Energy, UN, 1955, vol. 8, pp. 8-12.

${ }_{8}$ A. M. Gaudin, R. Schuhmann, Jr., and J. Dasher: Development of the Extraction Process for Uranium from South African GoldUranium Ores, Journal of Metals, 1956, vol. 8, No. 8, p. 1065; MINING ENGINEERING, 1956, vol. 8, No. 8, p. 802

${ }^{9} \mathrm{R}$. F. Hollis and C. K. McArthur: The Resin-in-Pulp Process for Recovery of Uranium, AIME Annual Meeting, New York, February 1956

${ }_{10}$ I. R. Higgins: Recovery of Uranium from Leach Slurries by Continuous Ion Exchange, EJC Nuclear Engineering and Science Congress, Cleveland, December 1955

$11 \mathrm{R}$. S. Welther: Ion Exchange and its Application to the Continuous Countercurrent Process, Creative Engr. Lab., Mechanical Engineering Dept., Massachusetts Institute of Technology.

${ }_{12}$ R. S. Long and R. S. Olson: AIME Annual Meeting, New York,

13 D. Kaufman and G. W. Lower: $A E C$ Report $A C C O-68$ (unclassi-

${ }_{14}$ J. Shankar, D. V. Bhalnagar, and T. K. S. Murthy: An Ion Exchange Process for the Recovery of Uranium from Carbonate Leach Solutions, International Conference on the Peaceful Uses of Atomic

$15 \mathrm{~K}$. A. Kraus: Journal, American Chemical Soc., 1955, vol. 77, p. 3972 .

${ }^{16}$ R. C. Nachod: U. S. Patent 2,371,119, Mar. 6, 1945

17 K. A. Kraus and G. E. Moore: Journal, American Chemical Soc., 1949 , vol. 71 , pp. 3263, 3855; 1950 , vol. 72, pp. 4293,5792

18 R. Kunin and R. J. Myers: Ion Exchange Resins. 1950. New York. John Wiley \& Sons.

${ }^{19}$ F. C. Nachod: Ion Exchange Theory and Application. 1950. New

York. Academic Press. by an Anion-Exchange Resin, Masters Thesis, Massachusetts Institute of Technology, June 1954 .

21 C. S. McLean and T. K. Prentice: The South African Uranium Industry, International Conference on the Peaceful Uses of Atomic Industry, International Conference on

${ }_{22}$ A. B. Mindler and C. F. Paulson: Engineering and Mining Journal, 1955 , vol. $3 A$, p. 156. Discussion of this paper sent (2 copies) to AIME by Mar. 1, 1957
will appear in AIME Transactions Vol. 209, 1957 , and in JourNal of METALS, October 1957 .

\title{
Technical Note Embrittling Effect of Molybdenum on Electrodeposited Copper
}

\author{
by H. R. Skewes
}

$\mathbf{I}^{\mathrm{N}}$ the course of small scale experiments on the electrodeposition of copper, extremely brittle deposits were obtained from electrolytes prepared by leaching calcined chalcopyrite with aqueous sulfuric acid. It was not possible to strip the metal without fracture after it had been deposited from such electrolytes onto smooth oiled copper sheets, the usual plant procedure for the production of so-called starting sheets. The embrittlement did not occur with electrolytes made either by leaching the calcine with water or by treating an acid leachate to remove iron as hydrous ferric oxide. The electrolytes which produced brittle deposits were found to contain molybdenum in concentrations of 10 to $25 \mathrm{mg}$ per I, whereas those which produced ductile deposits contained $<0.5 \mathrm{mg}$ per l. Synthetic electrolytes having the composition: $\mathrm{Cu}^{2+}, 40 \mathrm{gpl} ; \mathrm{Fe}^{2+}, 0.5$ to $1.0 \mathrm{gpl}$; $\mathrm{Fe}^{8+}, 0.5$ to $1.0 \mathrm{gpl}$; and $\mathrm{H}_{2} \mathrm{SO}_{4}, 10$ to $50 \mathrm{gpl}$, were prepared from reagent-grade salts; by adding ammonium molybdate, the embrittling effect of the higher concentrations of molybdenum (VI) was strikingly confirmed. The brittle deposits contained up to 0.03 pct Mo. The importance of oxidation state of the molybdenum was demonstrated when the electrolyte containing it was circulated continuously through a bed of fine copper metal during deposi-

H. R. SKEWES is associated with Div. of Industrial Chemistry, CSIRO, Melbourne, Australia.

TN 363D. Manuscript, June 12, 1956.

tion. Under these reducing conditions, the cathode deposit was ductile and molybdenum could not be detected.

Molybdenum has not been recognized as one of the metals causing embrittlement of copper nor is it listed among the usual impurities. In most electrowinning plants there is a purification step which removes iron from the leachate before electrolysis. In these cases molybdenum would be coprecipitated with hydrous ferric oxide. In the case of the large leaching plant at Chuquicamata, Chile, where the leachate is reported to contain considerable molybdenum, it would be reduced to a lower oxidation state during removal of chlorine by means of cement copper. This may explain why the embrittling effect of molybdenum has not been reported previously. Moreover, in copper refining plants where soluble anodes have been prepared by a high temperature smelting process, it is most unlikely that any molybdenum would remain with the copper, whereas the calcines in this work were prepared in a fluidized bed reactor at a temperature not exceeding $720^{\circ} \mathrm{C}$.

\section{Acknowledgment}

This work is part of an investigation on the roasting and extraction of copper from sulfide ores sponsored jointly by Mt. Morgan Ltd., Queensland, and the Mt. Lyell Mining and Railway Co. Ltd., Tasmania. 